Egyptian Journal of Aquatic Biology \& Fisheries

Zoology Department, Faculty of Science,

Ain Shams University, Cairo, Egypt.

ISSN $1110-6131$

Vol. 25(4): $221-240$ (2021)

www.ejabf.journals.ekb.eg

\title{
Global Warming, Marine Invertebrates, and Saudi Arabia Coast on the Red Sea:
} An updated review

\author{
Yaser S. Binnaser \\ Department of Biology, College of Science, Taibah University, Saudi Arabia \\ ysbinnaser@gmail.com
}

\begin{abstract}
ARTICLE INFO Article History:

Received: April 26, 2021

Accepted: June 5, 2021

Online: Aug. 3, 2021

Keywords:

Climate change,

Global warming,

Acidification,

Marine Invertebrates,

Red Sea.

ABSTRACT

Continuing humanitarian activities at their current pace will increase the accumulation of greenhouse gases emissions, as indicated by climate change scenarios proposed by many researchers. It is believed that the anthropogenic $\mathrm{CO}_{2}$ is the primary responsible for global warming in terrestrial environments and this rise led to the absorption of $\mathrm{CO}_{2}$ in the oceans, which increases the dangers marine animals may face during the coming decades. In addition to the high level of sea water, high water temperature, lack of oxygen, and salinity increase, it is also expected that the concentration of $\mathrm{CO}_{2}$ will rise, so that the chemistry of the sea water will move towards acidity. These impacts may have dire consequences on marine ecosystems and the biodiversity of marine organisms. It is believed that marine invertebrates (especially marine invertebrates with carbonic structures), will be highly vulnerable to global warming, threatening these species existence in their current locations or perhaps expose them to extinction. The Red Sea is a miniature ocean characterized by its biodiversity and the presence of a large number of coral reef communities. It is considered one of the most elevated marine systems in its temperature and salinity, but the researches on the impact of climate change on marine invertebrates are very few, especially in the middle region of the coast in the Kingdom of Saudi Arabia, which is the region that we invite researchers to shed light on.
\end{abstract}

\section{INTRODUCTION}

The most prominent indicators of climate change are observed in many climatic phenomena since 1950s, such as changes in temperature, the amount of precipitation, hurricanes, the resulting floods and high levels of saline seawater (Intergovernmental Panel on Climate Change (IPCC) 2014), and there is clear evidence of climate change, whether due to human activities or natural causes (Gravili, et al., 2017). These climate changes lead to remarkable alterations in natural habitats and ecosystems (Hanley, Bouma and Mossman, 2020), which may threaten the biodiversity of organisms and human food security (Banerjee et al., 2018), and if the global warming increased $1.5^{\circ} \mathrm{C}$ - 
$2.5^{\circ} \mathrm{C}$ it is expected to cause the extinction of $30 \%$ of known biological species (Dow and Downing, 2011).

\section{Global warming}

Anthropogenic activities, primarily the burning of fossil fuels and agricultural activities, have contributed to the emission of carbon dioxide $\left(\mathrm{CO}_{2}\right)$, methane $\left(\mathrm{CH}_{4}\right)$ and nitrous oxide $\left(\mathrm{N}_{2} \mathrm{O}\right)$ into the Earth's atmosphere, leading to the emergence of what is known as "global warming" (Dow and Downing, 2011). These daily emissions of greenhouse gases, will lead to climate change in the future for long periods of time as the effects cannot be reversed quickly, some of these gases remain only for few hours in the atmosphere or for days, while others remain for decades, centuries or thousands of years (Dow and Downing, 2011). $\mathrm{CO}_{2}$ and other greenhouse gases are likely to cause the Earth's surface temperature to rise to about $5^{\circ} \mathrm{C}$ above current levels before 2101, according to the RCP8.5 scenario with $\mathrm{CO}_{2}$ emissions of up to $1000 \mathrm{ppm}$, while it took nearly a hundred years in the past that air temperature rises by $0.85^{\circ} \mathrm{C}$ (IPCC, 2014).

About $71 \%$ of the planet's surface area is covered with seawater (such as: seas and oceans) (Levinton, 2009). So, global warming is likely to have more impact on the surface of oceans compared to deeper regions (Brierley and Kingsford 2009). The Earth's surface temperature is expected to increase much higher than the ocean's surface, where it has been observed that the ocean surface temperature has actually increased by $0.76^{\circ} \mathrm{C}$ since the nineteenth century (Findlay et al., 2008). Studies indicate that biodiversity can be affected by small changes in ocean temperature (Gravili et al., 2017), and forecasts indicate that ocean temperatures may increase to nearly $2{ }^{\circ} \mathrm{C}$ in the mid-2 $1^{\text {st }}$ century (IPCC, 2014), while it may reach more than $6^{\circ} \mathrm{C}$ at end of the $21^{\text {st }}$ century (YouJi, 2014). Sea levels except to rise about $0.5-0.8$ meters above 1990 levels by the end of this century, and it is likely will rise to more than one meter at that time due to the melting of glaciers and continental ice caps (Galland et al., 2009).

\section{High water temperature and its impact on living marine organisms}

Many organisms now live in temperatures close to their thermo tolerance limits (Somero, 2010). The increase in the behavioral activity of ectothermal marine organisms due to the rise in sea water temperature will lead to the high rate of oxygen consumption, and causes a decrease in the rate of energy stored in the body of the marine organisms, which may work to reduce the rate of physical growth (Levinton, 2009). Therefore, it is expected that global warming causes a decrease in the body size of the organisms (Mazurkiewicz et al., 2020). Thus, global warming can reduce overall animal biomass by affecting the animal's interaction with the food web due to an increase in energy demand and an increase in metabolic processes (Bruno, Carr and O'Connor, 2015). Experiments have shown a gradual decrease in the weight of the sea cucumber, 
Apostichopus japonicus, at the gradual increase in the temperature of the environment in which it lives. Such results reinforce fears that an additional increase in current temperatures may exacerbate the negative effects of global warming, as marine organisms are likely to be affected by ocean warming, and may emphasize the importance of predicting the effects of climate change on organisms to form a fairly clear picture reveals the effect of global warming on organisms as a result of the potential heat stress (Marigómez et al., 2017).

Climate change can affect animals indirectly by affecting critical natural habitats such as seaweeds and coral reefs, or through interactions of predators and other food mechanisms, adding to direct effects through physiological functions. Possibly the indirect effects of global warming associated with the food webs of organisms have had greater damage than is expected to result from the direct physiological effects. The coastal areas may suffer more from the direct effect of global warming on metabolism and reproductive periods and life cycles of marine organisms (Rossi et al., 2019). In the past 50 years, due to human activities, pollution and climate change, the rate of biodiversity loss has been accelerated, and continued climate change may by the end of this century cause the extinction of some marine organisms (Yanik and Aslan, 2018).

\section{Ocean acidification}

In addition to the great importance of the relationship between the temperatures of organisms and the environments in which they live there are other factors that have arisen from climate change and its study may contribute to predicting the future effects of climate change (Harley et al., 2006). The high concentration of $\mathrm{CO}_{2}$, the saturation status carbonate of seawaters and salinity are important factors affecting ecosystems, in addition to hypoxia and hydrostatic pressure (Liang $\boldsymbol{e t}$ al., 2020). The increase in human activity rates is accompanied by an increase in the levels of $\mathrm{CO}_{2}$ concentration in the atmosphere (Bibby et al., 2008), as the estimated value of $\mathrm{CO}_{2}$ in the atmosphere in 1750 it was 280 ppm (Widdicombe and Needham 2007), while this value reached 379 ppm in 2005 (De Bodt et al., 2009), and it reached $388 \mathrm{ppm}$ in the estimates for the 2010 (Dow and Downing, 2011).

The ocean has a natural ability to protect the atmosphere of the earth and the ocean surface is in balance with the atmosphere regarding $\mathrm{CO}_{2}$ and temperature. The higher concentrations of either of them in the atmosphere, the more they are in the oceans. These increases serve to change the physical and chemical properties of the oceans that operate as a giant reservoir of carbon dioxide absorption from the earth's atmosphere because of its large size. This absorption reduces the concentration of $\mathrm{CO}_{2}$ in the atmosphere, which may somewhat mitigate the effect of warming on the ecosystems on land, but it may cause severe consequences for the biological diversity of the marine ecosystems 
(Galland et al., 2009). This absorption of $\mathrm{CO}_{2}$ into seawaters reduced the $\mathrm{pH}$ of surface water by 0.1 units compared to levels recorded in the mid-eighteenth century (Salisbury and Jönsson, 2018), which represents a 30\% increase in acidity above 1750 levels (Dow and Downing, 2011). At the beginning of the current century, the sea's $\mathrm{pH}$ recorded an average of 8.11 (IPCC, 2014), but this figure is expected to decrease by 0.22 units in the current century's description to reach 7.88 (Vézina and Hoegh-Guldberg, 2008). However, it is expected that before 2101, these levels would reach 7.7 as low as 0.4 units, bringing the oceanic $\mathrm{CO}_{2}$ concentration to $1,200 \mathrm{ppm}$ (Arnold et al., 2009), while the $\mathrm{pH}$ of 6.7 is the projected estimate approximately 200 years later, with a decrease of 1.4 units compared to the current $\mathrm{pH}$ values (Harley et al., 2006). These decreases in the $\mathrm{pH}$ may cause severe adverse biotic effects on marine organisms, because these factors that increase the acidity of seawater affect the biodiversity, metabolism and ecosystems of marine organisms (Kleypas $\boldsymbol{e t}$ al., 2006). Therefore, we can define ocean acidification (OA) as: a decrease in the $\mathrm{pH}$ levels of ocean water resulting from the ocean surface absorption of $\mathrm{CO}_{2}$ from the earth's atmosphere (Schram et al., 2016).

Increased acidity in the seas affects marine organisms (Wood et al., 2008) which may have negative effects as the surface seawater temperature increases (Kurihara et al., 2004). These rises in acidity and temperature in the oceans are direct results of increased $\mathrm{CO}_{2}$ emissions into the atmosphere (Fabry et al., 2008). This acidification resulting from high levels of $\mathrm{CO}_{2}$ in the seas affects the physiology of certain marine organisms, causing damage to a group of marine invertebrates (Gutowska et al., 2008), such as the influence on sea urchins, crustaceans and mollusks (Wood et al., 2008). However, it is believed that marine organisms with exoskeletons (calcified) are most affected by the low $\mathrm{pH}$ of the oceans because their structures are composed of calcium carbonate $\mathrm{CaCO}_{3}$ (Harley et al., 2006), and a decrease in the $\mathrm{pH}$ of marine surfaces may lead to a decrease in the shell growth of some of the gastropod (Schram et al., 2016). In general, we do not know specifically what species will be affected by climate change and the extent of this impact (Speights et al., 2017). Hence the importance of the role of biologists and what they are doing in great efforts in this field to conduct studies of different types of organisms in various environments scattered around the globe, including marine ecosystems which containing nearly a quarter of global biodiversity on the planet (Davis et al., 2016).

Current studies indicate the importance of building carbon structures in regulating internal acidity and growth in calcified invertebrates (Pörtner, 2008), as metabolic rates are adversely affected by acidity levels in their bodies (Carr eno et al., 2012). Many marine organisms exposed to acidification of repeaters reduce their ability to build their shells and carbon structures, which affects their vital processes such as reproduction, behavior and general physiological functions (Tomatsuri and Kon, 2019). Also, acidification affects the ability of sea snails to take appropriate behavioral reactions 
against predation (Domenici $\boldsymbol{e t}$ al., 2017) by decreasing the $\mathrm{pH}$ of their bodies known as acidosis and increasing the concentration of $\mathrm{CO}_{2}$ (hypercapnia) (You-Ji, 2014). Therefore, it believes that many coral reef communities will be lose between the third and fifth decades of this century if greenhouse gases emissions rates continue to at the same current levels (Galland et al., 2009).

\section{Impact of climate change on marine invertebrates:}

In the first decade of the current century, many scientists became aware of the danger of ocean acidification, so research began in this field and continued until the present time. Some of them warn that these studies should combine the effect of high temperature and high $\mathrm{CO}_{2}$ concentration at seas.

In 1996, Batten and Bamber (1996) conducted an acidification experiment on Ragworm (Nereis virens) in two different periods. The first experiment was carried out in in the summer, specifically in August, which is an active time for these animals and the temperature was $18{ }^{\circ} \mathrm{C}$, while the second experiment took place at a time when animals were less active and it is in December of winter at a temperature of $9^{\circ} \mathrm{C}$. The animals were exposed to a $\mathrm{pH}$ from 5.1 to 8.1. It has been shown that when animals are exposed to a temperature of $18{ }^{\circ} \mathrm{C}$ and a $\mathrm{pH}$ of 6.5 or less, the damage begins to appear, as mortality increased ten days after the experiment began significantly. The $\mathrm{pH}$ of less than 6 caused the decrease in the level of glycogen. On the other hand, there were no cases of mortality during the 30 days from the start of the winter trial at a temperature of $9^{\circ} \mathrm{C}$, while there was a decrease in animal weight and a significant decrease in the level of glycogen. These results gave bad indicators on the life of Nereis virens and indicated that the temperature, the degree of $\mathrm{pH}$ and the concentration of carbon dioxide in seawater have an impact on the life of this species of animals, with critical $\mathrm{pH}$ levels varied from 6 to 7.5. This effect may be due to seasonality because animal was active at some times and less or inactive at other times. However, the use of sulfuric acid and its addition to seawater and high levels of acidity that the oceans may not reach during the next two hundred years have made scientists try to find better ways to obtain more realistic results.

\section{The efforts of scholars in the first decade of the twenty-first century:}

The term microcosms was shown by Courtney and Clements (2000) to place animals in small ponds but in an environment similar to the original environment filled with seawater, when studying a group of animals that follow under the Chironomidae family. In 2004, research was carried out on the embryos of two species of sea urchins: Hemicentrotus pulcherrimus and Echinometra mathaei by Kurihara et al. (2004) using carbon dioxide to adjust the acidity with a partial pressure of carbon dioxide $p \mathrm{CO}_{2}$ reached to $10,000 \mathrm{ppm}$ at $\mathrm{pH}$ of 6.8 , and for only 8 days. Using of this high concentration of carbon dioxide and for this brief period of this experiment resulted in a decrease in fertilization rates in both species of sea urchins, as the size of the larvae decreased and 
they lacked arms, and spicules, which indicates a very large decrease in the calcification rates.

The most significant change that occurred in the design of experiments carried out by Batten and Bamber (1996) on the effect of an acidification on the Rag worm (Nereis virens) in two different periods was proposed in 2007 by Widdicombe and Needham (2007) who developed a system of microcosms known as "mesocosm" which is a simulation to the natural environment in which the organisms live to a large deal. This design will be the basis for many experiences that will be discussed in this field. In this experiment, the authors (Widdicombe and Needham (2007) used carbon dioxide to manipulate partial pressure and change acidity. They conducted an experiment on the worm Nereis virens (ragworm), where it exposed for a period of five weeks (medium term) to an environment with an acidic medium of $\mathrm{pH}$ of 7.3, 6.5 and 5.6. The control group was exposed to an acidity of 7.9. This experiment, unlike what was mentioned earlier by Batten and Bamber (1996), showed tolerance for significant changes in $\mathrm{pH}$, as it showed no significant differences in metabolism or hiding activity, and did not show any effect of acidity on mortality. One of the disadvantages of this study was that the amount of sediments in containers compared on the size of the animal, which may have affected some products, such as hiding behavior.

The finding of the previous researches showed that the calcification rate of the coral reefs that were exposed to high levels of acidity decreased by $190 \%$, and these coral reefs showed a loss of pigment known as bleaching by up to $50 \%$ (Anthony et al., 2008). Likewise, (Jokiel et al., 2008) have studied the coral reefs and some organisms that have a suitable environment for growth and living, where large basins of mesocosms were used and were placed in same pools in the open air under natural sunlight, and for each pool they add $10 \%$ dilute hydrochloric acid $(\mathrm{HCl})$ to change the acidity. After ten months, they found a very large decrease in the number of samples from the vermeids (Serpulorbis sp.) and the barnacles (Balanus $s p$.) in acidifying treatments. There was also a decrease in the coral calcification rate of Montipora capitata from $15 \%$ to $20 \%$ compared to the control group. As for the booming weight, it decreased in Rhodolith compared to its rise in the control group with a negative growth rate of $250 \%$.

Finally, a decrease in the growth of crustose coralline algae appeared, with a relative decrease of $86 \%$. Returning to other marine invertebrates (Bibby et al., 2008) a study on blue mussel (Mytilus edulis) using four different levels of acidity has observed that the results indicate an influence in the physiological state and the dissolution of the calcium shell, as animals dissolve calcium carbonate $\left(\mathrm{CaCO}_{3}\right)$ and lower metabolic rates to maintain the internal acidity rate. The results obtained by Pörtner (2008) are contrasting with some experiments on some other invertebrates, which gave a significant decrease with statistically significant rates of growth and metabolism level. However, there were 
no significant differences in metabolic rate, growth and calcification that appeared excellent for cephalopod (Sepia officinalis) when animals were subjected to a high pressure. For carbon dioxide of 4000-6000 ppm, the $\mathrm{pH}$ value ranged from 7.10-7.23, at the same temperatures. As for (Wood $\boldsymbol{e t}$ al., 2008) obtained interesting results when conducted a 40 day of experiment on the ophiuroid brittlestar (Amphiura filiformis) that was treated under three levels of $\mathrm{pH}$ (7.7, 7.3 and 6.8), they found that there was an increase in growth and metabolism, and no noticeable difference is observed in the amount of calcium carbonate, in addition to that, the oxygen $\left(\mathrm{O}_{2}\right)$ absorption rates did not differ significantly from the control group treated with $\mathrm{pH}=8.0$. Again to blue mussels (Mytilus edulis) in an experiment carried out by Beesley et al. (2008) where they used the mesocosm system mentioned by Widdicombe and Needham (2007) to expose animals to three different levels of acidity (6.5, 7.6, 7.8 and 8.0), in addition to the control group for about two months.

According to Havenhand et al. (2008) by studying gametes and larvae of the sea urchin (Heliocidaris erythrogramma), it was found that sperm speed and ability to move in acidity seawaters were much lower than that of $\mathrm{pH}=8.1$. In another study on marine shrimp (Palaemon pacificus) conducted by Kurihara et al. (2008) used two types of treatments, the first treatment was carried out for 30 weeks at a $\mathrm{pH}$ of 7.89 and a partial pressure of $1000 \mathrm{ppm}$, while the second treatment continued for 15 weeks at a $\mathrm{pH}=7.64$ and $p \mathrm{CO}_{2}=1900 \mathrm{ppm}$; the temperature for the two treatments was adjusted at $25^{\circ} \mathrm{C}$. The results of showed a significant decrease in survival, with deaths in the first treatment reaching $45 \%$ at the beginning of the eighteenth week, while it was $35 \%$ in the second treatment at the beginning of the seventh week. On contrast, in another research carried out by Kurihara and Ishimatsu (2008) on the copepod (Acartia tsuensis) at $25^{\circ} \mathrm{C}, \mathrm{pH}=$ 7.31 and a carbon dioxide partial pressure of $2380 \mathrm{ppm}$, the results showed that there was no statistically significant effect on survival, growth speed and body size when compared to the control group at a $\mathrm{pH}=8.14$. These researches thus indicate that copepods are more tolerant of $\mathrm{CO}_{2}$ rise.

In 2009 research continued on ocean acidification and its impact on marine invertebrates more intensively. Although most of the research has taken carbon dioxide gas mainly to manipulate acidity levels, however, some researchers such as Andersson et al. (2009) still use some acids such as $\mathrm{HCl}$. For instance, one of the studies that was exposed to the effect of high temperature and low $\mathrm{pH}$ simultaneously was conducted on Heliocidaris eryhrogramma (Byrne et al., 2009). The organisms were exposed to three levels of a $\mathrm{pH}$ at 7.6, 7.8 and 7.8, coinciding with the temperatures at 20,24 and $26{ }^{\circ} \mathrm{C}$, respectively, and the control group was under the influence of $\mathrm{pH}=8.2$ and temperature at $20^{\circ} \mathrm{C}$. The results of this study showed that the responsibility lies with heat but not acidity in affecting fertilization and development in the animals being tested. Clark et al., (2009) 
collected larvae of four species of sea urchin in one study that included larvae of one species from tropical regions (Tripneustes gratilla), larvae of two species from temperate regions (Pseudechinus huttoni and Evechinus chloroticus), and the last species larvae from Polar regions (Sterechinus neumayeri). Carbon dioxide was used for acidification seawater to $\mathrm{pH}=7.8,7.7,7.5,7.0,6.5$ and 6.0 levels, as the larvae were exposed to these levels of $\mathrm{pH}$ for a period from 4 to 22 days.

The obtained results showed that, both types of temperate regions showed degradation in the form of larval structures, while the other two types of tropical and Polar Regions were not affect. Calcification in larval structures decreased significantly, with a statistically significant effect in larvae treated with low $\mathrm{pH}$ except for polar region. Also, the decrease in $\mathrm{pH}$ resulted in a decrease in the size of the larvae, as well as a decrease in survival in all species when the $\mathrm{pH}$ is less than 7.0.

One of the experiments that attempted to simulate the reality of $2100 \mathrm{ppm}$ levels as much as possible was the study of Ellis et al.( 2009) conducted on embryos of the marine intertidal gastropod (Littorina abtusata). Carbon dioxide was used to modify the acidity with a partial pressure of $1100 \mathrm{ppm}$ and a $\mathrm{pH} 7.6$, under a temperature of $15^{\circ} \mathrm{C}$, while the control group was below a $\mathrm{pH}$ 8.1. This study reached that the heart rates of the larvae and adults were significantly lower in the treated group with significantly acidified seawater. There were observed significant changes in physiological and behavioral patterns, as well as a decrease in the ability to grow, in addition to an increase in the duration of the larvae needed for growth and development.

Using flurochrome and the radioisotope ${ }^{45} \mathrm{Ca}$ in calcification estimates (Comeau et al., 2009) with a 6 hour study on pelagic mollusk (Limacina helicina) at a temperature of 5 ${ }^{\circ} \mathrm{C}$ there showed remarkable decrease in the rate of calcification of $28 \%$ when exposing animals to the $\mathrm{pH}$ level 7.78 and $\mathrm{pCO}_{2} 760 \mathrm{ppm}$ compared to the control group at $\mathrm{pH} 8.09$ and $p \mathrm{CO}_{2} 350 \mathrm{ppm}$ at the same temperature. These results represent a strong indication of the effect of carbon dioxide concentration on calcification rates. Hauton et al., (2009) used microcosms based on the system described by Widdicombe and Needham (2007) and with using carbon dioxide to manipulate $\mathrm{pH}$ levels to three concentrations $\mathrm{pH}(8.1$, 7.8 and 7.6) and $p \mathrm{CO}_{2}(380,550$ and $980 \mathrm{ppm})$, respectively on adults of the amphipod (Gammarus locusta) for 28 days at $20{ }^{\circ} \mathrm{C}$. The results concluded that this species of organism is strong and has a high ability to cope to the increase in acidity. No significant or statistically significant changes in growth and survival appeared compared to the control group. Likewise, Havenhand and Schlegel (2009) were conduct their study on the oyster (Crassostrea gigas), they did not find any statistically significant results on the influence of sperm motility and its ability to fertilize when exposing animals to a temperature of $21{ }^{\circ} \mathrm{C}-22{ }^{\circ} \mathrm{C}$ under $\mathrm{pH} 7.8$ compared to control group with $\mathrm{pH} 8.15$. 
Delayed larval development and change in shape as well as fetal abnormalities are the findings of Kurihara et al. (2008) when tested for larva of the mussel (Mytilus galloprovicialis) under high partial pressure of $2000 \mathrm{ppm}$ and $\mathrm{pH}=7.4$ at $14{ }^{\circ} \mathrm{C}$ for 6 days compared to the control group at $p \mathrm{CO}_{2}=380$ and $\mathrm{pH}=8.1$. By adding $\mathrm{NaOH}$ or $\mathrm{HCl}$ (Kuroyanagi et al., 2009) with a study that included three levels of acidification $(8,3,7,9$ and 7,7) for a period of 10 weeks on a type of anthracite called Margiopora kudakajimensis at a temperature of $25{ }^{\circ} \mathrm{C}$ compared to the control group $\mathrm{pH} 8.2$ there was no significant effect at 7,9. However, there was a significant decrease in growth and calcification rates when $\mathrm{pH}$ dropped to 7.7 .

Acidity has been studied on the larval development of the European lobster (Homarus gammarus) by Arnold et al. (2009) to study the growth of larvae in the early stages. The acidification did not have a direct effect on the calcification of the larvae. In cold water, at temperatures of $7.5^{\circ} \mathrm{C}$ and $9.9{ }^{\circ} \mathrm{C}$, Maier et al. (2009) have been experimenting the calcification rates with coral Lophelia pertusa. The results showed a decrease in the calcification rates reaching more than $50 \%$. In a study by Miller $\boldsymbol{e t}$ al. (2009) two species of oyster larvae were tested in the eastern oyster (Crassostrea virginica) and the suminoe oyster (Crassostrea ariakensis), where organisms were exposed to four levels of partial pressure of carbon dioxide $p \mathrm{CO}_{2} 280,380,560$ and $800 \mu \mathrm{atm}$, for a period of 4 weeks (28 days). The results indicated that there was no change in calcification and growth on $C$. ariakenis, while treatments for the year by $2100 \mathrm{ppm}$ conducted on C. virginica witnessed a decrease of $16 \%$ in the size of the shell and $42 \%$ in the calcium content compared to the pre-industrial era. So, this research continued similar to those recorded previously at the beginning of the second decade of the twentieth century, because climate change is so important to ecosystems and biodiversity, with the increasing evidence that scientists and researchers confirmed that.

\section{Methodology comparison:}

Looking to the studying phenomenon of acidification in climate change on marine organisms, it was find that most of them tried to simulate nature by using $\mathrm{CO}_{2}$ in acidification processes due to the belief that the negative impact is not only to acidity but to $\mathrm{CO}_{2}$ as well (Melatunan et al., 2013). On the other hand, though in small numbers the processes of acid development continued using strong acids such as Hydrochloric acid (HCl) (Kuroyanagi et al., 2009), which to some extent, succeeded in creating acidic atmospheres close to the expected in the coming decades. Few studies on the effect of climate change on marine animals have examined the effect of only the acidification factor (Pansch $\boldsymbol{e t}$ al., 2018), and such as the temperature elevated factor (Kaminski and Garrison, 2020). These factors are very important for marine organisms because the metabolic processes are very sensitive to temperatures changes for all marine invertebrates and also affect the geographical distribution of species and behavior in addition to their effect on ecosystems (Bruno et al., 2015) and evolution in ectothermal animals (Nguyen et al., 2011). 
Some scientists have also studied the effect of $\mathrm{O}_{2}$ (hypoxia) on marine organisms, because it is believed that in the year 2100 there may be a deficiency of up to $4 \%$ of $\mathrm{O}_{2}$ in the oceans (Cocco et al., 2013). A recent study found on the hydrostatic pressure factor because species migrate to deeper areas in the oceans due to elevated temperature and decrease oxygen in their recent areas, where it is believed that the vertical distribution of species is greatly affected by hydrostatic pressure as an ecological factor affecting the distribution marine species (Liang et al., 2020). On the other hand, some scientists are interested in conducting experiments to study the effects of synergies between several factors such as increased temperature and low $\mathrm{pH}$ in the oceans (Speights $\boldsymbol{e t}$ al., 2017), and the combination of increased salinity and increase surface seawater temperatures and studies on the effect of increased $\mathrm{CO}_{2}$ concentration and ocean oxygen deficiency (Cocco et al., 2013).

However, few scientists have studied the synergistic effect of more than two factors such as Salisbury and Jönsson (2018) who experimented the synergistic effect of increased seawater temperature with increased salinity and decreased $\mathrm{pH}$. These authors believed that simultaneous climate changes can lead to unexpected biological responses if it was compared to individual climate responses only. Many of these experiments were conducted in research laboratories (Domenici et al., 2017) using microcosms that simulate future environmental conditions on light of continuing greenhouse gas emissions, but some researchers believed that these experiments should be in the natural environments of marine organisms (Sorte and Bracken, 2015), but very few researchers combined experiments in research laboratories with experiments on the natural habitats of marine organisms (Meseck et al., 2020).

The studies also varied in the period of their conduct, ranging from long-term research that may extend for several months (Manríquez et al., 2016) due to the importance of knowing the extent of ability of different types of marine organisms adapt to climate change, or they will not be able to continue and will be damaged. However, some studies were carried out at the intermediate level for several weeks, during which animals were subjected to experimentation for a period of adaptation (Schram et al., 2016), while others had been conducted in the relatively short term through only several days (Wang et al., 2020), and there are also studies conducted in the very short term without periods of acclimatization (Comeau $\boldsymbol{e t}$ al., 2009). It may be very important to reconsider the expected significance of research conducted within hours to a few days that does not exceed a week.

\section{The importance of mollusks in global warming researches}

Mollusks comprise nearly 30,000 species and are believed to be of both calcified (which is believed to be most affected) and non-calcified species vulnerable to global 
warming in all of their life cycle (adult and larvae), both have economic and environmental catastrophic consequences (Parker $\boldsymbol{e t}$ al., 2013). Marine mollusks are a major component of the intertidal zone but competition and predation are determinants of distribution, intensity and biodiversity of mollusks in the intertidal zone in addition to temperature (Kaullysing et al., 2017). Marine mollusks are environmentally and economically important. For example the mussels and oyster beads that are found in estuaries and polluted areas obtaining their food by filtering seawater are also an important food source for other organisms (Parker et al., 2013). Snails also act as intermediate hosts of many parasites to complete their life cycle and thus are of medical importance (Al-khateeb 2009).

\section{Why the Red Sea?}

The Red Sea is a water area that extends $2250 \mathrm{~km}$ long. The maximum width of the Red Sea is in the south and up to $355 \mathrm{~km}$, compared with the narrowest point at the Bab al-Mandab strait varied from 30 - $40 \mathrm{~km}$ (Hereher, 2015), which connects the southern end of the Red Sea with the Indian ocean (Dreano et al., 2016). The average depth of the Red Sea is $490 \mathrm{~m}$, and the depth decreases at the Bab al-Mandab strait into $130 \mathrm{~m}$ (Bruckner et al., 2013). The Red Sea is a semi-closed water area that separates the Arabian Peninsula from the African continent (Hereher, 2015). Much of the Red Sea in Saudi Arabia is characterized by coastal corals, benthic seaweed, and mangroves (Dreano et al., 2016). The coast of the Kingdom of Saudi Arabia extends north on the Red Sea to reach the Gulf of Aqaba and south to the Farasan Islands (Bruckner et al., 2013), with a coastal extension of about $1840 \mathrm{~km}$, where it is the largest among of countries bordering this water basin and witnessing an accelerated civilization development (Hereher, 2016). The absence of rivers flowing into the Red Sea or everflowing water currents from the sea, as well as the presence of high levels of evaporation with a decrease in annual rainfall rates $(2 \mathrm{~cm} /$ year) (Dreano et al., 2016) led to high levels of salinity varied from 37 - 42 ppt (Koprivnikar and Poulin, 2009), and surface water temperatures rise to $32^{\circ} \mathrm{C}$ (Kandler $\boldsymbol{e t}$ al., 2019). Continued global warming is expected to lead to warming of the Red Sea, which began to rise markedly since the last decade of the twentieth century and continues to rise at a rate considered one of the highest observed (Raitsos et al., 2011).

The Red Sea is a region with high biodiversity of coral reefs and is located in the warmest regions in the world (Dreano et al., 2016). Despite the small size and abundance of species, it is still a water ecosystem that has not been adequately studied compared to the Caribbean Sea and the Great Barrier Reef (Berumen et al., 2013; Bruckner, et al., 2013). The number of research studies that examined the potential effects of climate change in the Red Sea is still very few, but those researches related to climate change and global warming are almost non-existent in the middle region of the Red Sea coasts along 
coasts of the Kingdom of Saudi Arabia, where there is a great difficulty to accessing such research. Berumen et al. (2013) mentioned in his research on coral reef studies in the Red Sea that it is about $80 \%$ less than the great barrier reef research and about $90 \%$ less than the research of the Caribbean Sea, and even those research on coral reefs, $50 \%$ of them were concentrated in the Gulf of Aqaba and the other $50 \%$ were distributed between the eastern and western coasts along the Red Sea. Because, as previously mentioned, there is no rivers flow on the Red Sea and due to the low amount of rain falling, high levels of salinity, heat and humidity, coral reefs flourished in the Red Sea. However, because of the exposure of coral reefs in the Red Sea to these difficult climatic conditions it is believed that they are very durable to climatic conditions and may withstand to be from the last coral reefs that will remain in the oceans (Nasr et al., 2020). Same observations from the lack of researches in the Red Sea found by Kandler et al.( 2019) during his research about the impact of climate change on sponges in the Red Sea when compared to research in the Caribbean Sea and the Great Barrier Reef.

\section{CONCLUSION}

We tried to obtain scientific papers related to the effect of climate change and global warming on marine organisms from the Palanaxidae family or any other species of marine snails or other calcified invertebrates that inhabit the middle region of the Red Sea. The results were very disappointing, and there are few studies were found on the potential impacts of the climate change on coral reefs in the Red Sea. Although the climatic effects on other animals that have a significant environmental and economic importance are not fully known, the severity of the impacts is not predictable for all organisms on the same levels and yet there are no sufficient studies to clarify how the region might look in the near or far perspective. Therefore, there is still need for further publishing good publications that reflect the importance of the Red Sea's middle region on the coast of the Kingdom of Saudi Arabia. These publications will help in setting a vision for future forecasts of the potential effects of global warming on the ecosystems and the biodiversity of those regions with a strategic and important location as it is in addition to abundant with many areas of distinctive coral reef systems in its biodiversity includes coastal cities with a population density city (Jeddah), economic city (Thowal) and industrial city (Yanbu). These cities had has been increased the importance of the region and the need for more research interest in it to monitor natural habitats such as islands and coral reef areas, including the organisms they contain and preserve them from the future impacts of climate change and global warming.

\section{Acknowledgement}

The author would like to thank Nada M. Hijab for providing language editing of the manuscript. 


\section{Funding}

This research did not receive any specific grant from funding agencies in the public, commercial, or not-for-profit sectors.

\section{REFERENCES}

Al-khateeb, S. O. (2009): Effect of body weight and acclimated temperature on the respiration physiology on seawater snail Planaxis sulcatus. Journal of University of Anbar for Pure Science, 3(1). Available at: https://www.iasj.net/ /article/15514 (Accessed: April 23, 2021).

Andersson, A. J.; Kuffner, I. B.; Mackenzie, F. T.; Jokiel, P. L.; Rodgers, K. S. and Tan, A. (2009) : Net Loss of CaCO3 from a subtropical calcifying community due to seawater acidification: Mesocosm-scale experimental evidence. Biogeosciences, 6(8): 1811-1823. doi: 10.5194/bg-6-1811-2009.

Anthony, K. R. N. ; Kline D. I.; Diaz-Pulido, G. Dove, S.and Hoegh-Guldberg O. Ocean acidification causes bleaching and productivity loss in coral reef builders. PNAS, 2008, 105(45): 17442-17446.

Arnold, K. E.; Findlay, H. S.; Spicer, J.; Daniels, C. and Boothroyd, D. (2009): Effect of $\mathrm{CO} 2$-related acidification on aspects of the larval development of the European lobster, Homarus gammarus(L.). Biogeosciences, 6(8): 1747-1754. doi: 10.5194/bg-6-1747-2009.

Banerjee, S.; Samanta, S. and Chakraborti, P. K. (2018): Impact of Climate Change on Coastal Agro-Ecosystems, In: Lichtfouse E. (eds) Sustainable Agriculture Reviews 33. Sustainable Agriculture Reviews, 33. Springer, Cham. pp. 115-133. https://doi: 10.1007/978-3-319-99076-7_4.

Batten, S. D. and Bamber, R. N. (1996): The effects of acidified seawater on the polychaete Nereis virens Sars, 1835. Marine Pollution Bulletin, 32(3): 283-287. doi: 10.1016/0025-326X(95)00163-H.

Beesley, A.; Lowe D. M.; Pascoe C. and Widdicombe S. (2008): Effects of CO2-induced seawater acidification on the health of Mytilus edulis. In: Climate Research, pp. 215-225. doi: 10.3354/cr00765.

Berumen, M. L.; Hoey, A. S.; Bass, W. H.; Bouwmeester, J. Catania, D.; Cochran, J. E. M.; Khalil, M. T.; Miyake, S.; Mughal, M. R.; Spaet, J. L. Y. and SaenzAgudelo P. (2013): The status of coral reef cology research in the Red Sea. Coral Reefs, Springer, pp. 737-748. doi: 10.1007/s00338-013-1055-8.

Bibby, R.; Widdicombe, S.; Parry, H.; Spicer, J. and Pipe, R. (2008): Effects of ocean acidification on the immune response of the blue mussel Mytilus edulis. Aquatic Biology, 2(1): 67-74. doi: 10.3354/ab00037. 
De Bodt, C.; Van Oostende, N.; Harlay, J.; Sabbe, K. and Chou, L. (2009): Individual and interacting effects of pCO2 and temperature on Emiliania huxleyi calcification: study of the calcite production, the coccolith morphology and the coccosphere size. Biogeosciences Discussions. doi: 10.5194/bgd-6-11127-2009.

Brierley, A. S. and Kingsford, M. J. (2009): Impacts of Climate Change on Marine Organisms and Ecosystems. Current Biology. Cell Press, pp. R602-R614. doi: 10.1016/j.cub.2009.05.046.

Bruckner, A.; Rowlands, G.; Riegl, B.; Purkis, S.; Williams, A. and Renaud, P. (2013): Atlas of Saudi Arabian Red Sea Marine Habitats. Available at: https://www.livingoceansfoundation.org/publication/red-sea-atlas-english/ (Accessed: April 23, 2021).

Bruno, J. F.; Carr, L. A. and O'Connor, M. I. (2015): Exploring the role of temperature in the ocean through metabolic scaling. Ecology, 96(12): 3126-3140. doi: 10.1890/14-1954.1.

Byrne, M. Ho M; Selvakumaraswamy, P.; Ngyen; Dworjanyn, S. A. and Davis, A R. (2009): Temperature, but not $\mathrm{pH}$, compromises sea urchin fertilization and early development under near-future climate change scenarios. Proceedings of the Royal Society B: Biological Sciences, 276(1663): 1883-1888. doi: 10.1098/rspb.2008.1935.

Carreno, C. A.; Clifton, R. G.; Hauth, J. C. and Myatt, L. (2012): Excessive early gestational weight gain and risk of gestational diabetes mellitus in nulliparous women. Obstetrics and Gynecology, 119(6): 1227-1233. doi: 10.1097/AOG.0b013e318256cf1a.

Clark, D.; Lamare, M. and Barker, M. (2009): Response of sea urchin pluteus larvae (Echinodermata: Echinoidea) to reduced seawater $\mathrm{pH}$ : A comparison among a tropical, temperate, and a polar species. Marine Biology, 156(6): 1125-1137. doi: 10.1007/s00227-009-1155-8.

Cocco, V.; Joos, F.; Steinacher, M.; Frolicher, T. L. and Bopp, L. (2013): Oxygen and indicators of stress for marine life in multi-model global warming projections," Biogeosciences, 10(3): 1849-1868. doi: 10.5194/bg-10-1849-2013.

Comeau, S.; Gorsky, G.; Jeffree, R. A.; Teyssié, J.-L. and Gattuso J-P. (2009): Impact of ocean acidification on a key arctic pelagic mollusc (Limacina helicina). Biogeosciences, 6(9): 1877-1882. doi: 10.5194/bg-6-1877-2009.

Courtney, L. A. and Clements, W. H. (2000): Sensitivity to acidic pH in benthic invertebrate assemblages with different histories of exposure to metals. Journal of the North American Benthological Society, 19(1): 112-127. doi: $10.2307 / 1468285$. 
Davis, K. E.; Hill, J.; Astrop, T. I. and Wills M A. (2016): Global cooling as a driver of diversification in a major marine clade. Nature Communications, 7(1):1-8. doi: 10.1038/ncomms 13003 .

Domenici, P.; Torres, R. and Manriquez, P. H. (2017): Effects of elevated carbon dioxide and temperature on locomotion and the repeatability of lateralization in a keystone marine mollusc. Journal of Experimental Biology, 220(4): 667-676. doi: 10.1242/jeb.151779.

Dow, K. and Downing, T. E. (2011): The Atlas of Climate Change: Mapping the World's Greatest Challenge by Kirstin Dow. Myriad Editions Limited. Available at: https://www.goodreads.com/book/show/824678.The_Atlas_of_Climate_Change (Accessed: April 23, 2021).

Dreano, D.; Raitso, D. E.; Gittings, J.; Krokos, G. and Hoteit I. (2016): The Gulf of Aden Intermediate Water Intrusion Regulates the Southern Red Sea Summer Phytoplankton Blooms. PLOS ONE. Edited by G. Han, 11(12): e0168440. doi: 10.1371/journal.pone.0168440.

Ellis, R. P.; Bersey, J.; Rundle, S. D.; Hall-Spencer, J. and Spicer J. (2009): Subtle but significant effects of $\mathrm{CO} 2$ acidified seawater on embryos of the intertidal snail, Littorina obtusata. Aquatic Biology, 5(1): 41-48. doi: 10.3354/ab00118.

Fabry, V. J.; Seibel, B. A.; Feely, R. A. and Orr J. C. (2008): Impacts of ocean acidification on marine fauna and ecosystem processes, in ICES Journal of Marine Science. Oxford Academic, pp. 414-432. doi: 10.1093/icesjms/fsn048.

Findlay, H.; Kendall, M.; Spicer, J.; Turley, C. M. and Widdicombe S. (2008): Novel microcosm system for investigating the effects of elevated carbon dioxide and temperature on intertidal organisms. Aquatic Biology, 3(1): 51-62. doi: Galland, Grantly R. and HerrDorothee (2009): The ocean And Climate change : Tools and Guidelines For Action | IUCN. Available at: https://www.iucn.org/content/oceanand-climate-change-tools-and-guidelines-action-0 (Accessed: April 23, 2021).

Gravili, C.; Cozzoli, F. and Boero, F. (2017): The historical reconstruction of distribution of the genus Halecium (Hydrozoa: Haleciidae): a biological signal of ocean warming? Marine Biology Research, 13(5): 587-601. doi: 10.1080/17451000.2017.1290805.

Gutowska, M.; Pörtner, H. and Melzner, F. (2008): Growth and calcification in the cephalopod Sepia officinalis under elevated seawater pCO2. Marine Ecology Progress Series, 373: 303-309. doi: 10.3354/meps07782.

Hanley, M. E.; Bouma, T. J. and Mossman, H. L. (2020): The gathering storm: Optimizing management of coastal ecosystems in the face of a climate-driven threat. Annals of Botany, Oxford University Press, pp. 197-212. doi: 


\subsection{3/aob/mcz204.}

Harley, C. D. G; Hughes, A. R.; Hultgren, K. M. and Miner, B. G. (2006): The impacts of climate change in coastal marine systems. Ecology Letters. Ecol Lett, pp. 228241. doi: 10.1111/j.1461-0248.2005.00871.x.

Hauton, C.; Tyrrell, T. and Williams, J. (2009): The subtle effects of sea water acidification on the amphipod Gammarus locusta. Biogeosciences, 6(8): 14791489. doi: 10.5194/bg-6-1479-2009.

Havenhand, J. N.; Buttler, F-;, Thorndyke, M C. and Williamson, J. E. (2008): Nearfuture levels of ocean acidification reduce fertilization success in a sea urchin. Current Biology, Cell Press, pp. R651-R652. doi: 10.1016/j.cub.2008.06.015.

Havenhand, J. N. and Schlegel, P. (2009): Near-future levels of ocean acidification do not affect sperm motility and fertilization kinetics in the oyster Crassostrea gigas. Biogeosciences, 6(12): 3009-3015. doi: 10.5194/bg-6-3009-2009.

Hereher, M. E. (2015): Assessment of Egypt's Red Sea coastal sensitivity to climate change. Environmental Earth Sciences, 74(4): 2831-2843. doi: 10.1007/s12665015-4304-z.

Hereher, M. E. (2016): Vulnerability assessment of the Saudi Arabian Red Sea coast to climate change. Environmental Earth Sciences, 75(1): 1-13. doi: 10.1007/s12665015-4835-3.

IPCC, 2014: (2014): Climate Change 2014 Fifth Assessment Synthesis Report - IPCC. Available at: https://ar5-syr.ipcc.ch/ (Accessed: April 23, 2021).

Jokiel, P. L.; Rodgers, K. S.; Kuffner, I. B.; Andersson, A. J.; Cox, E. F. and Mackenzie F. T. (2008): Ocean acidification and calcifying reef organisms: A mesocosm investigation. Coral Reefs, 27(3): 473-483. doi: 10.1007/s00338-0080380-9.

Kaminski, M. A. and Garrison, T. F. (2020): Thermoregulatory Behavior in the Tropical Periwinkle Planaxis sulcatus. Arabian Journal for Science and Engineering, 45(6): 4817-4822. doi: 10.1007/s13369-019-04300-z.

Kandler, N.; Wooster, M. K.; Leray, M.; Knowlton, N.; de Voogd, N J.; Paulay, G and Berumen, M. L. (2019): Hyperdiverse Macrofauna Communities Associated with a Common Sponge, Stylissa carteri, Shift across Ecological Gradients in the Central Red Sea. Diversity, 11(2): 18-25. doi: 10.3390/d11020018.

Kaullysing, D.; Taleb-Hossenkhan, N.; Kulkarni, B. and Bhagooli, R. (2017): A first field report of various coral-eating gastropods and associated infestations around Mauritius Island, Western Indian Ocean. Western Indian Ocean Journal of Marine Science, 1/2017: 73-75. 
Kleypas, J. A; Feely, R.; Fabry, V. J;. Langdon, C.; Chris, S. and Robbins, L. (2006): Impacts of Ocean Acidification on Coral Reefs and Other Marine Calcifiers: A Guide for Future Research Contributing Authors. Available at: http://www.fedworld.gov/onow/ (Accessed: April 23, 2021).

Koprivnikar, J. and Poulin, R. (2009): Effects of temperature, salinity, and water level on the emergence of marine cercariae. Parasitology Research, 105(4): 957-965. doi: 10.1007/s00436-009-1477-y.

Kurihara, H.; Asai, T.; Kato, S. and Ishimatsu, A. (2008): Effects of elevated pCO2 on early development in the mussel Mytilus galloprovincialis. Aquatic Biology, 4(3): 225-233. doi: 10.3354/ab00109.

Kurihara, H.; Matsui, M.; Matsui, M.; Furukawa, H.; Hayashi, M. and Ishimatsu, A. (2008): Long-term effects of predicted future seawater $\mathrm{CO} 2$ conditions on the survival and growth of the marine shrimp Palaemon pacificus. Journal of Experimental Marine Biology and Ecology, 367(1): 41-46. doi: 10.1016/j.jembe.2008.08.016.

Kurihara, H. and Ishimatsu, A. (2008): Effects of high CO2 seawater on the copepod (Acartia tsuensis) through all life stages and subsequent generations. Marine Pollution Bulletin, 56(6): 1086-1090. doi: 10.1016/j.marpolbul.2008.03.023.

Kurihara, H.; Shimode, S. and Shirayama, Y. (2004): Sub-lethal effects of elevated concentration of $\mathrm{CO} 2$ on planktonic copepods and sea urchins," Journal of Oceanography. Springer, pp. 743-750. doi: 10.1007/s10872-004-5766-x.

Kuroyanagi, A.; Kawahata, H.; Suzuki, A. and Fujita, Irie T. (2009): Impacts of ocean acidification on large benthic foraminifers: Results from laboratory experiments. Marine Micropaleontology, 73(3-4): 190-195. doi: 10.1016/j.marmicro.2009.09.003.

Liang, L.; Chen, J. Li. and Yanan Zhang, H. (2020): Insights into high-pressure acclimation: Comparative transcriptome analysis of sea cucumber Apostichopus japonicus at different hydrostatic pressure exposures. BMC Genomics, 21(1): 6874. doi: 10.1186/s12864-020-6480-9.

Levinton, J. S. (2009): Marine Biology: Function, Biodiversity, Ecology: Levinton, Jeffrey S.: 9780199857128: Amazon.com: Books. Oxford University Press New York.. Available at: https://www.amazon.com/Marine-Biology-FunctionBiodiversity-Ecology/dp/0199857121 (Accessed: April 23, 2021).

Maier, C.; Hegeman, J.; Weinbauer, H. G. and Gattuso, J-P.(2009): Calcification of the cold-water coral lophelia pertusa under ambient and reduced $\mathrm{pH}$. Biogeosciences, 6(8): 1671-1680. doi: 10.5194/bg-6-1671-2009.

Manríquez, P. H.; Jara, M E.; Seguel, M. E.; Torres, R. and Alarcon, E. (2016): Ocean 
Acidification and Increased Temperature Have Both Positive and Negative Effects on Early Ontogenetic Traits of a Rocky Shore Keystone Predator Species. PLOS ONE. Edited by H. G. Dam, 11(3): p. e0151920. doi: 10.1371/journal.pone.0151920.

Marigómez, I.; Mugica, M.; Izagirre, U. and Sokolova, I. M. (2017): Chronic environmental stress enhances tolerance to seasonal gradual warming in marine mussels. PLoS ONE, 12(3). doi: 10.1371/journal.pone.0174359.

Mazurkiewicz, M.; Gorska, B.; Renaud, P E. and Włodarska-Kowalczuk, M. (2020): Latitudinal consistency of biomass size spectra - benthic resilience despite environmental, taxonomic and functional trait variability. Scientific Reports, 10(1): 1-12. doi: 10.1038/s41598-020-60889-4.

Melatunan, S.; Calosi, P.; Rundle, S. D.; Widdicombe, S. and Moody, A. J. (2013): Effects of ocean acidification and elevated temperature on shell plasticity and its energetic basis in an intertidal gastropod. Marine Ecology Progress Series, 472: 155-168. doi: 10.3354/meps10046.

Meseck, S. L.; Sennefelder, G.; Krisak, M. and Wikfors, G. H. (2020): Physiological feeding rates and cilia suppression in blue mussels (Mytilus edulis) with increased levels of dissolved carbon dioxide. Ecological Indicators, 117, p. 106675. doi: 10.1016/j.ecolind.2020.106675.

Miller, A. W.; Reynolds, A. C.; Sobrino, C. and Riedel, G. F. (2009): Shellfish Face Uncertain Future in High CO2 World: Influence of Acidification on Oyster Larvae Calcification and Growth in Estuaries. PLoS ONE. Edited by Z. Finkel, 4(5), p. e5661. doi: 10.1371/journal.pone.0005661.

Nasr, R. S.; Althaewi, K. Derbah, M. S;. Gharibo, S. O. and Fallatah, S. A. (2020): Prevalence and predictors of postpartum depression in Riyadh, Saudi Arabia: A cross sectional study," PLoS ONE, 15(2). doi: 10.1371/journal.pone.0228666.

Nguyen, K. D. T.; Morley, S. A.; Lai, C-H.; Clark, M. S. and Tan, K S. (2011): Upper Temperature Limits of Tropical Marine Ectotherms: Global Warming Implications. PLoS ONE. Edited by C. A. Navas, 6(12), p. e29340. doi: 10.1371/journal.pone.0029340.

Pansch, C.; Hattich, G. S. I.; Heinrichs, M E;. Pansch, A. and Zagrodzka, Z. (2018): Long-term exposure to acidification disrupts reproduction in a marine invertebrate. PLOS ONE. Edited by A. C. Anil, 13(2), p. e0192036. doi: 10.1371/journal.pone.0192036.

Parker, L. M.; Ross, P. M.; O’Connor, W. A.; Pörtner, H. O.; Elliot, Scanes and Wright J. M. (2013): Predicting the response of molluscs to the impact of ocean acidification. Biology. MDPI AG, pp. 651-692. doi: 10.3390/biology2020651. 
Pörtner, H. O. (2008): Ecosystem effects of ocean acidification in times of ocean warming: A physiologist's view. Marine Ecology Progress Series, 373: 203-217. doi: $10.3354 /$ meps 07768 .

Raitsos, D. E.; Hoteit, I.; Prihartato, P. K.; Chronis, G. and Triantafyllou, Y. (2011): Abrupt warming of the Red Sea. Geophysical Research Letters, 38(14), p. n/a-n/a. doi: 10.1029/2011GL047984.

Rossi, S.; Gravili, C.; Milisenda, G.; Bosch-Belmar, M.; De Vito, D. and Piraino, S. (2019): Effects of global warming on reproduction and potential dispersal of Mediterranean Cnidarians. European Zoological Journal. Taylor and Francis Ltd., pp. 255-271. doi: 10.1080/24750263.2019.1631893.

Salisbury, J. E. and Jönsson, B. F. (2018): Rapid warming and salinity changes in the Gulf of Maine alter surface ocean carbonate parameters and hide ocean acidification. Biogeochemistry, 141(3): 401-418. doi: 10.1007/s10533-018-05053.

Schram, J. B.; Schoenrock, K. M.; McClintock, J. B.; Amsler, C. D. and Angus, R. A. (2016): Testing Antarctic resilience: the effects of elevated seawater temperature and decreased $\mathrm{pH}$ on two gastropod species. ICES Journal of Marine Science, 73(3): 739-752. doi: 10.1093/icesjms/fsv233.

Seuront, L.; Ng, T. P. T. and Lathlean, J. A. (2018): A review of the thermal biology and ecology of molluscs, and of the use of infrared thermography in molluscan research. Journal of Molluscan Studies. Oxford University Press, pp. 203-232. doi: 10.1093/mollus/eyy023.

Somero, G. N. (2010): The physiology of climate change: How potentials for acclimatization and genetic adaptation will determine 'winners' and 'losers. Journal of Experimental Biology, 213(6): 912-920. doi: 10.1242/jeb.037473.

Sorte, C. J. B. and Bracken, M. E. S. (2015): Warming and Elevated CO2 Interact to Drive Rapid Shifts in Marine Community Production. PLOS ONE. Edited by D. E. Naya, 10(12), p. e0145191. doi: 10.1371/journal.pone.0145191.

Speights, C. J.; Silliman, B. R. and McCoy, M. W. (2017): The effects of elevated temperature and dissolved $\mathrm{\rho CO} 2$ on a marine foundation species. Ecology and Evolution, 7(11): 3808-3814. doi: 10.1002/ece3.2969.

Tomatsuri, M. and Kon, K. (2019): Impacts of ocean acidification on hermit crab communities through contrasting responses of Pagurus filholi (de Man, 1887) and Clibanarius virescens (Krauss, 1843). Aquatic Ecology, 53(4): 569-580. doi: 10.1007/s10452-019-09709-0.

Vézina, A. F. and Hoegh-Guldberg, O. (2008): Effects of ocean acidification on marine ecosystems: Introduction. Marine Ecology Progress Series, 373, 199-201. doi: 


\subsection{4/meps07868}

Wang, X.; Shang, Y.; Kong, H.; Hu, M.; Yang, J. and Deng, Y. (2020): Combined effects of ocean acidification and hypoxia on the early development of the thick shell mussel Mytilus coruscus. Helgoland Marine Research, 74(1): 3. doi: 10.1186/s10152-020-0535-9.

Widdicombe, S. and Needham, H. R. (2007): Impact of CO2-induced seawater acidification on the burrowing activity of Nereis virens and sediment nutrient flux. Marine Ecology Progress Series, 341: 111-122. doi: 10.3354/meps341111.

Wood, H. L.; Spicer, J. I. and Widdicombe, S. (2008): Ocean acidification may increase calcification rates, but at a cost. Proceedings of the Royal Society B: Biological Sciences, 275(1644): 1767-1773. doi: 10.1098/rspb.2008.0343.

Yanik, T. and Aslan, I. (2018): Impact of global warming on aquatic animals. Pakistan Journal of Zoology. University of Punjab (new Campus), pp. 353-363. doi: 10.17582/journal.pjz/2018.50.1.353.363.

You-Ji, W. (2014): The Future of Marine Invertebrates in Face of Global Climate Change Global Warming and Sea Temperature Rise. doi: 10.4172/1410-5217.1000e105. 